\title{
Financial Development and Poverty Reduction: Evidence from Selected African Countries
}

\author{
Yaya Keho ${ }^{1}$ \\ ${ }^{1}$ Ecole Nationale Supérieure de Statistique et d'Economie Appliquée (ENSEA) Abidjan. 08 BP 03 Abidjan 08, Côte \\ d'Ivoire
}

Correspondence: Yaya Keho, Ecole Nationale Supérieure de Statistique et d'Economie Appliquée (ENSEA) Abidjan. 08 BP 03 Abidjan 08, Côte d'Ivoire. Tel: 225-22-444-124.

Received: May 18, 2017

Accepted: June 5, $2017 \quad$ Online Published: September 16, 2017

doi:10.5430/ijfr.v8n4p90

URL: https://doi.org/10.5430/ijfr.v8n4p90

\begin{abstract}
This paper examines the relationship between financial development, economic growth and poverty reduction in nine African countries for the period 1970-2013. It uses the ARDL bounds testing approach. The results show evidence of long-run relationship among the variables in height countries with GDP and financial deepening having a positive effect on poverty reduction in five countries (Benin, Cameroon, Cote d'Ivoire, Gabon and South Africa), and poverty reduction having a positive effect on economic growth in three countries (Ghana, Nigeria and Senegal). The study also reveals bidirectional long-run causality between economic growth and poverty reduction in Cote d'Ivoire, Gabon and South Africa, and bidirectional long-run causality between finance and poverty reduction in Benin, Cameroon and South Africa. These findings suggest that policies aimed at increasing economic growth and improving access to credit would reduce poverty but also that measures of poverty reduction would lead to economic growth and financial deepening in these countries.
\end{abstract}

Keywords: poverty reduction, financial development, economic growth, African countries

\section{Introduction}

Since the work of Shumpeter (1912), numerous studies examined the role of financial sector development in promoting economic growth (see De Gregorio \& Guidotti, 1995; Arestis \& Demetriades, 1997; Ram, 1999; Andersen \& Tarp, 2003; Ghirmay, 2004; Levine et al., 2000). Although the evidence from these studies is inconclusive, it is widely believed that financial development enhances economic growth and consequently policies that lead to a deepening of the financial sector have been advocated. The development of the financial sector and economic growth also may have positive effects on poverty reduction. Financial development can contribute to poverty reduction directly by facilitating transactions and allowing the poor to benefit from financial services that increase their income. Financial development also can reduce poverty indirectly by stimulating economic growth. In contrast to the outpouring of works on the finance-growth and growth-poverty relationships, empirical studies on the finance-poverty nexus is relatively limited. Besides, results from these studies are mixed across countries and methodologies. Furthermore, Sub-Saharan African countries have received little attention. This study attempts to fill the gap for a sample of nine selected African countries that have not previously covered. It investigates whether access to credit can contribute to reduce poverty in Sub-Saharan African countries, and which of the direct and indirect effects is predominant in poverty reduction. Poverty reduction represents a major challenge for Sub-Saharan Africa. For instance, the poverty headcount ratio at $\$ 1.90$ a day for Sub-Saharan Africa rose from $56.8 \%$ in 1990 to $57.1 \%$ in 2002 and has gently declined to $42.7 \%$ in 2012 (Poverty and Equity Databank online, World Bank, 2015). This ratio varies across countries with Nigeria having 53.5\% in 2009, Kenya 33.6\% in 2005 and Cote d'Ivoire $29 \%$ in 2008. Using national standards, it is estimated that about 53.8\% of people in South Africa in 2010, $46 \%$ in Nigeria in $2009,45.6 \%$ in Kenya in 2005 , and $42.7 \%$ in Cote d'Ivoire in 2008 live below the poverty line. Poverty has become a predominant theme in the policy discussion on economic development. The first Goal of the UN Millennium Declaration of 2000 is eradication of extreme poverty and hunger, and the first target for this goal is to halve, between 1990 and 2015, the proportion of people whose income is below $\$ 1.25$ per day. The progress that different regions have made towards achieving this goal is hopeful. However, Sub-Saharan Africa will be the only region that will fail to meet the goal by 2015 . In that context, responsiveness of poverty to increase in credit is of 
obvious interest. An analysis of this relationship not only helps to understand the role of financial deepening in sustainable development but also sets a framework for discussion of financial policies. Despite the significant implications of this issue the relationship between financial development and poverty reduction has not been explored too much for Sub-Saharan African countries.

The remainder of the study is organized as follows. Section 2 reviews the literature on the relationship between finance and poverty reduction. Section 3 outlines the econometric methodology. Section 4 presents the empirical results of the study. Finally, Section 5 provides summary and gives some policy implications.

\section{Literature Review}

Theoretically the development of the financial sector can contribute to poverty reduction in a number of ways. First, deep financial sector improves the opportunities for the poor to access formal finance by addressing the causes of financial market failures such as information asymmetry and the high fixed cost of lending to small borrowers (Jalilian \& Kirkpatrick, 2002; Odhiambo, 2009; Rajan \& Zingales, 2001). Indeed, many factors limit the access of the poor to formal financial market. Among these factors are the lack of guarantee, the high lending interest rates, and the absence a formal financial institution specialized in financial services for the poor. The well-known McKinnon (1973) conduit effect suggests that even if financial institutions do not provide credit to the poor they provide transaction services and saving opportunities which could improve their income. This effect is likely to hold in low financially developed economies with credit constraints. Second, financial development eradicates the credit constraints on poor households and improves their access to credit facilities and deposits. Through better access to credit and financial services, the poor can strengthen their productive assets by using productivity-enhancing technologies or investing in education and health, which in turn increases their income and thus reduces poverty (Shahbaz, 2009; Inoue \& Hamori, 2012).

Besides the direct effect of financial deepening on poverty reduction, financial sector development can also help to reduce poverty indirectly by stimulating economic growth through its impact on capital accumulation and the rate of technological progress (De Gregorio, 1996). The positive effects of a developed financial sector on economic growth have long been reported in many empirical studies (Arestis \& Demetriades, 1997; De Gregorio \& Guidotti, 1995; Ghirmay, 2004). The hypothesis is made here that economic growth is beneficial to the poor. The empirical studies show that economic growth is good for the poor and that higher per capita income countries have less poverty (Datt \& Ravallion, 1992; Kakwani, 2000; World Bank, 2001; Dollar \& Kraay, 2002; Besley \& Burgess, 2003; Kraay, 2004). However, as noted by Besley and Burgess (2003) and Pradhan (2010), economic growth is not a sufficient condition for poverty reduction, the level of income inequality also matters. High inequality could undermine the benefit of growth for the poor. If financial development increases income inequality, then poor cannot benefit from the expected positive economic growth.

On the empirical front, a growing body of literature has examined the interaction between financial development and poverty reduction. The empirical evidence from this literature is however mixed and controversial across countries, data and methodologies. For instance, Jalilian and Kirkpatrick (2002) and Jalilian and Kirkpatrick (2005) used panel data for a sample of 42 countries and found that financial development reduces poverty in developing countries. Shahbaz (2009) investigated the impact of financial development and financial instability on poverty reduction in Pakistan. Using the autoregressive distributed lag model (ARDL) and economic growth, inflation, agricultural growth, manufacturing and trade openness as controlling variables, He found that financial development reduces poverty while financial instability increases it. In addition, agriculture growth, manufacturing and trade openness reduce poverty. Applying the Johansen cointegration test on Indian data covering the period 1951-2008, Pradhan (2010) found that poverty reduction causes economic growth and vice versa. In addition, financial development causes poverty reduction and economic growth causes financial development. Ho and Odhiambo (2011) explored the relationship between financial development and poverty reduction in China for the period 1978 to 2008. The results are sensitive to the finance variable. When the credit ratio is used, a feedback effect exists between financial development and poverty reduction in the short run. However, results for broad money supply ratio show bidirectional causal flow in the short run but poverty reduction causes financial development in the long run. Perez-Moreno (2011) analyzed the causal relationship between financial development and poverty reduction for a sample of 35 developing economies. He found unidirectional causality running from financial development to poverty reduction. Inoue and Hamori (2012) examined whether financial deepening has contributed to poverty reduction in India. Using unbalanced panel data for 28 Indian states over seven time periods, they found that financial deepening significantly decreases poverty, after controlling for trade openness, inflation rate and economic growth. Khan et al. (2012) reinvestigated the impact of financial development on poverty reduction in Pakistan for 
the period 1981-2010 by using several indicators of financial development. Applying the ARDL bounds testing approach to cointegration, their results suggest that financial development reduces poverty. Uddin et al. (2012) examined the relationship between financial development and poverty reduction in the case of Bangladesh. Using data over the period of 1976-2010 and the ARDL bounds testing approach to cointegration, they found short-run bidirectional causality between the development of the financial sector and poverty reduction. Using similar estimation technique with structural breaks, Uddin et al. (2014) reached the same finding for Bangladesh over the period of 1975-2011. They also found that economic growth is accelerated by financial development and poverty reduction. Chemli (2014) used the ARDL approach to examine the relationship between financial development and poverty reduction in 8 MENA countries (Algeria, Egypt, Iran, Jordan, Mauritania, Morocco, Tunisia and Yemen) over the period of 1990-2012. Their results show that financial development favors the poor. Also, GDP per capita and trade openness affect positively the household final consumption expenditure per capita.

Regarding Sub-Saharan African countries, very few studies have been made to empirically examine the finance and poverty reduction nexus. Odhiambo (2009) examined the relationship between finance, growth and poverty reduction in South Africa over the period from 1960 to 2006. Using the Johansen cointegration tests, He found that an increase in economic growth leads to an increase in financial development as measured by money ratio to GDP. He also reported that both financial development and economic growth Granger cause poverty reduction in South Africa in the short and long run. Odhiambo (2010a) found that financial development Granger causes domestic savings and hence poverty reduction in Kenya. Using annual data over the period 1969-2006, Odhiambo (2010b) investigated causality between financial development and poverty in the case of Zambia. The causality analysis reported that when the ratio of broad money (M2) to nominal GDP is used as an indicator of financial development, poverty reduction proxied by private per capita consumption causes the development of the financial sector. However, when domestic credit to private sector as share of GDP is used, financial development Granger causes poverty reduction. Aye (2013) used the Johansen cointegration to examine the dynamic causal relationship between financial deepening, economic growth and poverty in Nigeria over the period 1960-2011. The results support the indirect channel through which finance affects poverty via growth. They also found evidence of causality from poverty to financial deepening. Dauda and Makinde (2014) used VAR model to examine the nexus between financial sector development and poverty reduction in Nigeria over the period 1980-2010. The results show that economic growth exerts the strongest influence on poverty reduction in the short run but could be detrimental to the poor in the long run due to the adverse effect of income inequality. Furthermore, financial deepening proxied by broad money supply (M2) is negatively related to poverty. However, contrary to the general belief, credits to private sector do not cause a reduction in the incidence of poverty. The authors attributed this result to the wrong attitude of financial intermediaries that have not adequately channeled savings to the pro-poor sectors of the economy.

\section{Model, Data and Methodology}

\subsection{Model Specification}

The model used in this paper is built on the following relationship:

$$
P_{t}=f\left(F_{t}, Y_{t}\right)
$$

where $\mathrm{P}$ is poverty indicator, $\mathrm{F}$ is an indicator of financial development and $\mathrm{Y}$ is real GDP per capita. For the estimation purpose, Eq.(1) is represented by the following logarithm equation:

$$
P_{t}=\beta_{0}+\beta_{1} F_{t}+\beta_{2} Y_{t}+\mu_{t}
$$

It is expected that economic growth $(\mathrm{Y})$ and financial development $(\mathrm{F})$ benefit the poor by giving them better access to goods and services and enhancing their well-being.

This relationship is estimated for nine Sub-Saharan countries, namely Benin, Cameroon, Cote d'Ivoire, Gabon, Ghana, Kenya, Nigeria, Senegal and South Africa. Given that time series data on poverty in African countries are very limited, we use household final consumption per capita as a proxy for poverty (see also Odhiambo, 2009; Khan et al. 2012; Aye, 2013; Uddin et al., 2014; Chemli, 2014). The ratio of domestic credit to private sector by banks as share of GDP is used as an indicator of financial development. This indicator measures the role of financial intermediaries in channeling funds to private agents. We include per capita real GDP as control variable. Poverty and per capita real GDP are in constant 2005 US dollars. The study covers the time period from 1970 to 2013 except for Nigeria for which data start from 1980. The data are obtained from the World Development Indicators by the Word 
Bank. In the empirical analysis all variables are used in their natural logarithms.

\subsection{Bounds Testing Approach to Cointegration}

To examine the long-run relationship between financial deepening, economic growth and poverty reduction, this study makes use of the autoregressive distributed lag (ARDL) bounds test developed by Pesaran et al. (2001). This methodology has certain econometric advantages over standard methods. In particular, it allows the use of variables which have different order of integration (I (0) and I (1)), and also provides better results for small sample data as compared to alternative methods (Haug, 2002). It can distinguish dependent and independent variables.

To implement the bounds testing procedure, Eq.(2) is modelled as a conditional ARDL-ECM equation as follows:

$$
\Delta P_{t}=\theta_{0}+\theta_{1} P_{t-1}+\theta_{2} F_{t-1}+\theta_{3} Y_{t-1}+\sum_{i=1}^{p} \gamma_{1 i} \Delta P_{t-i}+\sum_{i=0}^{p} \gamma_{2 i} \Delta F_{t-i}+\sum_{i=0}^{p} \gamma_{3 i} \Delta Y_{t-i}+\mu_{t}
$$

The first step in the ARDL approach is to estimate Eq.(3) using ordinary least square (OLS). The second step is to trace the presence of cointegration by restricting all estimated coefficients of lagged level variables equal to zero. That is, the null hypothesis of no cointegration $\theta_{1}=\theta_{2}=\theta_{3}=0$ is tested by the mean of an $F$-test, denoted by $\mathrm{F}_{\mathrm{P}}$. The asymptotic critical values are provided by Pesaran et al. (2001). Without having any a priori information about the direction of the long-run relationship among the three variables, the bound test equation can be estimated taking each of the variables in turn as a dependent variable.

\subsection{Granger Causality Analysis}

To provide more knowledge on the relationship between finance and poverty, the study further examines the direction of causality between the variables using the Granger causality analysis. In the presence of a long-run relationship, Granger-causality test requires the inclusion of a lagged error correction term within a vector error correction model (VECM). Accordingly, Granger-causality analysis involves estimating the following system of equations:

$$
(1-L)\left[\begin{array}{c}
P_{t} \\
F_{t} \\
Y_{t}
\end{array}\right]=\left[\begin{array}{l}
\varphi_{1} \\
\varphi_{2} \\
\varphi_{3}
\end{array}\right]+\sum_{i=1}^{p}(1-L)\left[\begin{array}{lll}
\beta_{1 i} & \gamma_{1 i} & \phi_{1 i} \\
\beta_{2 i} & \gamma_{2 i} & \phi_{2 i} \\
\beta_{3 i} & \gamma_{3 i} & \phi_{3 i}
\end{array}\right] \times\left[\begin{array}{c}
P_{t-i} \\
F_{t-i} \\
Y_{t-i}
\end{array}\right]+\left[\begin{array}{c}
\lambda_{1} \\
\lambda_{2} \\
\lambda_{3}
\end{array}\right] E C T_{t-1}+\left[\begin{array}{l}
e_{1 t} \\
e_{2 t} \\
e_{3 t}
\end{array}\right]
$$

where (1-L) stands for the difference operator and $\mathrm{ECT}_{\mathrm{t}-1}$ denotes the lagged residuals of the long-run relationship. Coefficients on $\mathrm{ECT}_{\mathrm{t}-1}$ capture the speed of adjustment of the variables in response to a deviation from their long-run equilibrium path. The significance of the differenced explanatory variables based on F-statistics or Wald-statistics indicates the existence of short-run causality, whereas the significance of $\mathrm{ECT}_{\mathrm{t}-1}$ based on t-statistics indicates the existence of long-run causality (Granger et al. 2000). For instance, $\gamma_{1 i} \neq 0$ shows that financial development Granger-causes poverty reduction whereas the reverse causality is indicated by $\beta_{2 i} \neq 0$.

\section{Empirical Results}

Table 1 reports some descriptive statistics on the three variables in their natural logarithms. The most striking feature is the low level of financial deepening in most countries. South Africa has the highest average level of financial development. The statistics also indicate disparity in real per capita GDP with Gabon having the highest level followed by South Africa. The Jarque-Bera statistic reports values lower than 5.99 in most cases, suggesting that most of examined variables follow a normal distribution. As can be seen, poverty is predominant in Sub-Saharan Africa. Indeed, about 53.8\% of people in South Africa in 2010, 46\% in Nigeria in 2009, 45.6\% in Kenya in 2005 and 40\% in Cameroon in 2007 live below the national poverty line. Table 1 also suggests a positive correlation between financial development and poverty reduction. However, correlation does not mean causality. The aim of this study is to find out whether this positive association implies that more credit to private agents causes higher consumption or higher consumption leads to more credit to private agents. It is possible that the association between the two variables is not causal in any direction but just coincidental. 
Table 1. Descriptive statistics of variables (in natural logarithm)

\begin{tabular}{|c|c|c|c|c|c|c|c|c|c|c|}
\hline \multirow{2}{*}{ Country } & \multicolumn{3}{|l|}{ Mean } & \multicolumn{3}{|c|}{ Median } & \multicolumn{3}{|l|}{ JB stat. } & \multirow{2}{*}{$\begin{array}{c}\text { Poverty } \\
\text { ratio (year) }\end{array}$} \\
\hline & $\mathrm{P}$ & $\mathrm{F}$ & $Y$ & $\mathrm{P}$ & $\mathrm{F}$ & $\mathrm{Y}$ & $\mathrm{P}$ & $\mathrm{F}$ & $\mathrm{Y}$ & \\
\hline Benin & 6.005 & 2.793 & 6.176 & 6.012 & 2.953 & 6.158 & 0.694 & 3.162 & 2.679 & $36.2(2011)$ \\
\hline Cameroon & 6.461 & 2.705 & 6.828 & 6.463 & 2.651 & 6.822 & 0.567 & 3.696 & 1.221 & 39.9 (2007) \\
\hline Cote d'Ivoire & 6.673 & 3.176 & 7.094 & 6.681 & 3.261 & 7.023 & 0.987 & 5.374 & 4.637 & 42.7 (2008) \\
\hline Gabon & 7.672 & 2.582 & 8.852 & 7.686 & 2.587 & 8.846 & 1.320 & 0.834 & 13.854 & $32.7(2005)$ \\
\hline Ghana & 5.876 & 1.869 & 6.102 & 5.858 & 1.770 & 6.067 & 2.981 & 2.798 & 5.151 & $24.2(2012)$ \\
\hline Kenya & 5.942 & 3.072 & 6.249 & 5.951 & 3.056 & 6.240 & 18.180 & 1.618 & 54.450 & 45.9 (2005) \\
\hline Nigeria & 6.120 & 2.648 & 6.495 & 6.170 & 2.581 & 6.380 & 1.956 & 14.151 & 4.426 & 46.0 (2009) \\
\hline Senegal & 6.303 & 3.138 & 6.591 & 6.286 & 3.188 & 6.588 & 1.668 & 2.238 & 2.205 & $46.8(2011)$ \\
\hline South Africa & 7.992 & 4.046 & 8.567 & 7.967 & 3.992 & 8.560 & 5.146 & 2.848 & 2.129 & $53.8(2010)$ \\
\hline
\end{tabular}

Source: World Development Indicators Online, World Bank. Poverty ratio is obtained using national poverty line.

Before proceeding with the empirical analysis, we carry out some preliminary investigations of the data in terms of stationarity. This step is important in order to ensure that variables are not integrated of order two or higher. Moreover, the bounds test requires the dependent variable to be a I(1) series. To this end, we perform the well-known unit root test of Phillips and Perron (1988). This test has been performed under the model with constant and trend for the level series and with constant for series in first difference. The results displayed in Table 2 show that the variables under study are I(1) in all countries except Kenya for which all variables are stationary.

Table 2. Results of unit root tests

\begin{tabular}{llccccc}
\hline Country & $\mathrm{P}$ & $\mathrm{F}$ & $\mathrm{Y}$ & $\Delta \mathrm{P}$ & $\Delta \mathrm{F}$ & $\Delta \mathrm{Y}$ \\
\hline Benin & -2.588 & -1.854 & -2.777 & -9.779 & -6.260 & -7.872 \\
Cameroon & -2.191 & -1.667 & -1.911 & -6.294 & -4.622 & -4.210 \\
Cote d'Ivoire & -2.953 & -2.348 & -1.712 & -6.044 & -5.299 & -4.391 \\
Gabon & -2.795 & -2.593 & -3.529 & -8.028 & -7.357 & -4.406 \\
Ghana & -1.992 & -2.085 & -0.143 & -7.205 & -6.008 & -4.057 \\
Kenya & -4.920 & -3.869 & -4.292 & -10.693 & -9.156 & -5.382 \\
Nigeria & -3.253 & -2.276 & -2.529 & -7.254 & -8.594 & -4.678 \\
Senegal & -2.542 & -1.991 & -1.543 & -6.565 & -4.776 & -7.883 \\
South Africa & -1.322 & -2.962 & -0.808 & -3.575 & -7.288 & -4.234 \\
\hline
\end{tabular}

Notes: Critical values at the 5\% level are -3.518 (level) and -2.933 (difference).

The results of the bounds F-test statistics along with the long-run estimates are displayed in Table 3. In bounds testing procedure, lag length on each variable was selected using the general-to-specific approach with maximum lag set to five. From the table we can see that the computed F-statistic exceeds the upper critical values at $5 \%$ level of significance for the height countries. Accordingly, for these countries we reject the null hypothesis of no cointegration among the variables and conclude that there is a long-run relationship among financial development, income and poverty reduction. CUSUM and CUSUMSQ tests for parameter stability reveal no evidence of parameter instability over the period of analysis. The estimates of the long-run parameters indicate that financial development and per capita income contribute to poverty alleviation in Benin, Cameroon, Cote d'Ivoire, Gabon and South Africa. Therefore, economic policies that promote financial deepening and economic growth have positive long run effects on the average private consumption of these countries. In the case of Ghana, Nigeria and Senegal where cointegration was found when per capita GDP is the dependent variable, poverty reduction is positively related to economic growth. 
Table 3. Results of bounds test for cointegration

\begin{tabular}{llllcccc}
\hline Country & $\mathrm{F}_{\mathrm{P}}$ & $\mathrm{F}_{\mathrm{F}}$ & $\mathrm{F}_{\mathrm{Y}}$ & \multicolumn{3}{c}{ Long-run relationship } \\
\cline { 5 - 7 } & & & & Dep. var. & $\beta_{1}$ & $\beta_{2}$ \\
\hline Benin & $7.685(5)$ & $8.267(3)$ & $5.098(4)$ & $\mathrm{P}$ & $0.061(4.326)$ & $0.607(2.947)$ \\
Cameroon & $11.700(4)$ & $6.169(3)$ & $11.709(4)$ & $\mathrm{P}$ & $0.049(2.111)$ & $0.625(11.470)$ \\
Côte d'Ivoire & $5.334(3)$ & $4.390(3)$ & $3.322(5)$ & $\mathrm{P}$ & $0.084(1.919)$ & $0.446(4.116)$ \\
Gabon & $5.697(5)$ & $1.721(3)$ & $7.025(4)$ & $\mathrm{P}$ & $0.690(3.766)$ & $1.839(2.078)$ \\
Ghana & $3.037(3)$ & $4.052(5)$ & $8.994(3)$ & $\mathrm{Y}$ & $0.089(1.300)$ & $1.691(2.723)$ \\
Nigeria & $3.807(3)$ & $12.484(3)$ & $13.604(3)$ & $\mathrm{Y}$ & $0.433(3.929)$ & $0.914(4.606)$ \\
Senegal & $4.420(3)$ & $5.374(3)$ & $6.600(4)$ & $\mathrm{Y}$ & $0.071(0.507)$ & $1.941(2.092)$ \\
South Africa & $5.064(4)$ & $8.954(4)$ & $4.983(4)$ & $\mathrm{P}$ & $0.128(1.909)$ & $0.850(22.525)$
\end{tabular}

Note: $\mathrm{P}, \mathrm{F}$ and $\mathrm{Y}$ are the symbols for log of real per capita private consumption, financial development and real per capita GDP, respectively. $\mathrm{F}_{\mathrm{z}}$ denotes the F-statistic when $\mathrm{z}$ serves as the dependent variable. Values in (.) indicate the case under which the bounds test was applied. Critical values for F-statistics are taken from Pesaran et al. (2001). $\beta_{1}$ and $\beta_{2}$ are the long-run coefficients in $\mathrm{P}=\beta_{0}+\beta_{1} \mathrm{~F}+\beta_{2} \mathrm{Y}$ or $\mathrm{Y}=\beta_{0}+\beta_{1} \mathrm{~F}+\beta_{2} \mathrm{P}$ with t-statistics in parenthesis.

The results of the Granger-causality tests are presented in Table 4. The results of the long-run causality show both that financial development and economic growth Granger cause the reduction of poverty in Benin, Cameroon, Cote d'Ivoire, Gabon and South Africa. Furthermore, poverty reduction and economic growth contribute to financial deepening in Benin, Cameroon and South Africa. Results also reveal that poverty reduction and financial development are growth-enhancing in Cote d'Ivoire, Gabon, Ghana, Nigeria, Senegal and South Africa. In other words, the results suggest bidirectional long-run causality between finance and poverty reduction for Benin, Cameroon and South Africa, and bidirectional long-run causality between economic growth and poverty reduction for Cote d'Ivoire, Gabon and South Africa. The results indicate that economic growth causes financial development in Cameroon, Ghana, and Senegal. This result is consistent with the demand-following hypothesis. The larger the economic growth, the higher the demand for funds by private agents, which leads to further financial development. Financial development causes economic growth in Gabon, Ghana, and Nigeria.

With respect to the short-run causality, the results in Table 4 suggest a causal relationship running from finance to poverty reduction only in South Africa and a causality running from economic growth to poverty reduction in Kenya and South Africa. In addition, poverty reduction Granger causes financial development in Cameroon, and poverty reduction causes economic growth in Gabon, Ghana and South Africa. Conversely, no short-run causal relationship exists between the three variables for Benin and Cote d'Ivoire.

Table 4. Results of Granger Causality Tests

\begin{tabular}{llllllll}
\hline \multirow{2}{*}{ Country } & Lag & \multicolumn{2}{l}{ Short-run causality } \\
\cline { 3 - 8 } & $\mathrm{F} \rightarrow \mathrm{P}$ & $\mathrm{P} \rightarrow \mathrm{F}$ & $\mathrm{Y} \rightarrow \mathrm{P}$ & $\mathrm{P} \rightarrow \mathrm{Y}$ & $\mathrm{F} \rightarrow \mathrm{Y}$ & $\mathrm{Y} \rightarrow \mathrm{F}$ \\
\hline Benin & 1 & $0.830(0.362)$ & $0.936(0.333)$ & $0.981(0.321)$ & $1.032(0.309)$ & $1.351(0.245)$ & $0.103(0.747)$ \\
Cameroon & 4 & $0.733(0.947)$ & $20.731(0.000)^{*}$ & $1.858(0.761)$ & $2.837(0.585)$ & $3.114(0.538)$ & $22.198(0.000)^{*}$ \\
Cote d'Ivoire & 1 & $0.002(0.961)$ & $0.001(0.968)$ & $0.817(0.366)$ & $0.419(0.517)$ & $0.025(0.872)$ & $1.587(0.207)$ \\
Gabon & 5 & $8.417(0.134)$ & $0.541(0.990)$ & $6.436(0.266)$ & $15.102(0.009)^{*}$ & $9.922(0.077)^{* *}$ & $0.587(0.988)$ \\
Ghana & 5 & $4.553(0.472)$ & $5.081(0.406)$ & $7.088(0.214)$ & $20.466(0.001)^{*}$ & $20.897(0.000)^{*}$ & $9.704(0.084)^{* * *}$ \\
Kenya & 2 & $1.373(0.266)$ & $1.440(0.250)$ & $6.947(0.003)^{*}$ & $0.649(0.528)$ & $0.332(0.719)$ & $1.732(0.192)$ \\
Nigeria & 5 & $4.946(0.422)$ & $6.505(0.260)$ & $8.969(0.110)$ & $6.159(0.291)$ & $15.843(0.007)^{* *}$ & $7.936(0.159)$ \\
Senegal & 1 & $0.890(0.345)$ & $1.385(0.239)$ & $1.193(0.274)$ & $0.362(0.547)$ & $0.053(0.817)$ & $3.495(0.061)^{* *}$ \\
South Africa & 1 & $3.531(0.060)^{* *}$ & $0.999(0.317)$ & $16.091(0.000)^{*}$ & $11.669(0.000)^{*}$ & $1.280(0.257)$ & $0.000(0.993)$ \\
\hline
\end{tabular}




\begin{tabular}{llll}
\hline & \multicolumn{3}{l}{ Long-run causality: $\mathrm{ECT}_{\mathrm{t}-1}=0$} \\
\cline { 2 - 4 } & Poverty $(\mathrm{P})$ & Finance $(\mathrm{F})$ & Growth $(\mathrm{Y})$ \\
\hline Benin & $-0.646(0.011)^{*}$ & $2.190(0.025)^{*}$ & $0.083(0.606)$ \\
Cameroon & $-1.030(0.036)^{*}$ & $-0.819(0.001)^{*}$ & $-1.032(0.157)$ \\
Cote d'Ivoire & $-0.704(0.001)^{*}$ & $0.052(0.878)$ & $-0.338(0.019)^{*}$ \\
Gabon & $-0.760(0.006)^{*}$ & $-0.498(0.460)$ & $0.719(0.001)^{*}$ \\
Ghana & $0.101(0.663)$ & $1.371(0.049)^{*}$ & $-0.205(0.009)^{*}$ \\
Nigeria & $0.081(0.845)$ & $0.806(0.325)$ & $-0.581(0.009)^{*}$ \\
Senegal & $-0.001(0.347)$ & $0.001(0.449)$ & $-0.0001(0.023)^{*}$ \\
South Africa & $-1.133(0.000)^{*}$ & $1.496(0.057)^{* *}$ & $-0.636(0.013)^{*}$ \\
\hline
\end{tabular}

Note: Statistics for Short-run causality are Chi2-statistics with $p$-values in parentheses. Statistics for long-run causality are coefficients on $\mathrm{ECT}_{\mathrm{t}-1}$ with $p$-values in parentheses. The asterisks $*$ and $* *$ denote statistical significance at the $5 \%$ and $10 \%$ levels, respectively.Overall, the results suggest that growth and financial deepening measured as credit to private sector could be beneficial to the poor in some Sub-Saharan African countries. An increase in economic growth and credit to households can help to reduce poverty in Benin, Cameroon, Cote d'Ivoire, Gabon and South Africa. On the other hand, in most countries measures of poverty reduction would lead to economic growth and financial deepening in the long run.

\section{Conclusion and Policy Implications}

This study examined the relationship between financial development, economic growth and poverty reduction in nine selected Sub-Saharan African countries over the period 1970 to 2013. To this end, we first performed unit root tests and then applied the ARDL bounds testing and Granger causality tests.

The empirical analysis showed evidence of long-run relationship among the variables in height countries with GDP and finance having a positive long-run effect on poverty reduction in five countries (Benin, Cameroon, Cote d'Ivoire, Gabon and South Africa), and poverty reduction having a positive effect on economic growth in three countries (Ghana, Nigeria and Senegal). The findings from Granger causality analysis are mixed across countries. They reveal bidirectional long-run causality between economic growth and poverty reduction for Cote d'Ivoire, Gabon and South Africa, and bidirectional long-run causality between finance and poverty reduction for Benin, Cameroon and South Africa. These findings suggest that policies aimed at increasing economic growth and access to credit would help to reduce poverty but also that measures of poverty reduction would lead to economic growth and financial deepening in these countries. Furthermore, the study also found that poverty reduction and financial deepening Granger-cause economic growth in Ghana, Nigeria and Senegal.

If economic growth is effective in increasing the average level of private consumption why does it fail to reduce poverty in most African countries? The results of this study support the widely-held view that economic growth is a necessary but not a sufficient condition for achieving poverty reduction. The extent of the social impact of economic growth depends on the growth rate itself and also on the level of income inequality. To accelerate poverty reduction economic growth needs to be more inclusive to reach all groups of society including the poor segment of population. Governments should also adopt measures improving access to credit to the poor that will be helpful for curbing poverty through creating more employment opportunities.

Before closing, we must stress that this study brings home the usefulness of country case studies. Considering concerns about poverty, this topic is very relevant to be researched into the more. Therefore, the econometric technique employed in this study can be extended to include large sample of African countries. The effects of other relevant variables such as inflation, tax policy, public spending and trade openness can be investigated. Another interesting topic that has not been investigated in previous empirical studies is the presence of structural change and nonlinear adjustment in the relationship between financial development, economic growth and poverty reduction. Structural changes and nonlinearities may occur due to price shocks, financial crises, shifts in monetary policy, changes in preferences, and political instability. It is well known that structural changes and nonlinearities lower the power of standard test of stationarity and cointegration. Using threshold or regime shift models to reexamine the finance and poverty nexus would be an interesting topic for further research. 


\section{References}

Andersen, T. B., \& Tarp, F. (2003). Financial Liberalization, Financial Development and Economic Growth in LDCs. Journal of International Development, 15(2), 189-209. https://doi.org/10.1002/jid.971

Arestis, P., \& Demetriades, P. (1997). Financial Development and Economic Growth: Assessing the Evidence. Economic Journal, 107, 783-799. https://doi.org/10.1111/j.1468-0297.1997.tb00043.x

Aye, G. C. (2013). Causality between Financial Depending, Economic Growth and Poverty in Nigeria. The Business \& Management Review, 3(3), 1-12.

Besley, T., \& Burgess, R. (2003). Halving Global Poverty. Journal of Economic Perspectives, 17(3), 3-22. https://doi.org/10.1257/089533003769204335

Chemli, L. (2014). The Nexus among financial development and poverty reduction: An Application of ARDL Approach from the MENA Region. Journal of Economics and Development Studies, 2(4), 125-134. https://doi.org/10.15640/jeds.v2n4a9

Datt, G., \& Ravallion, M. (1992). Growth and redistribution components of changes in poverty measures: a decomposition with applications to Brazil and India in the 1980s. Journal of Development Economics, 38(2), 275-295. https://doi.org/10.1016/0304-3878(92)90001-P

Dauda, R. O., \& Makinde, K. O. (2014). Financial sector development and poverty reduction in Nigeria: a vector autoregression analysis (1980-2010). Asian Economic and Financial Review, 4(8), 1040-1061.

De Gregorio, J. (1996). Borrowing constraints, human capital accumulation and growth. Journal of Monetary Economics 37(1), 49-71. https://doi.org/10.1016/0304-3932(95)01234-6

De Gregorio, J. \& Guidotti, P. E. (1995). Financial Development and Economic Growth. World Development, 23(3), 433-448. https://doi.org/10.1016/0305-750X(94)00132-I

Dollar, D., \& Kraay, A. (2002). Growth is good for the poor. Journal of Economic Growth, 7, 195-225. https://doi.org/10.1023/A:1020139631000

Ghirmay, T. (2004). Financial development and economic growth in Sub-saharan African countries: evidence from time series analysis. African Development Review, 16(3), 415-432. https://doi.org/10.1111/j.1017-6772.2004.00098.x

Granger, C. W. J., Huang, B. N., \& Yang, C. W. (2000). A bivariate causality between stock prices and exchange rates: evidence from recent Asianflu. The Quarterly Review of Economics and Finance, 40(3), 337-354. https://doi.org/10.1016/S1062-9769(00)00042-9

Haug, A. A. (2002). Temporal aggregation and the power of cointegration tests. a Monte Carlo study. Oxford Bulletin of Economics and Statistics, 64(4), 399-412. https://doi.org/10.1111/1468-0084.00025

Ho, S. Y., \& Odhiambo, M. N. (2011). Finance and poverty reduction in China: an empirical investigation. International Journal of Business and Economics Research, 10(8), 103-114. https://doi.org/10.19030/iber.v10i8.5382

Inoue, T., \& Hamori, S. (2012). How has financial deepening affected poverty reduction in India? empirical analysis using state-level panel data. Applied Financial Economics, 22(5), 395-408. https://doi.org/10.1080/09603107.2011.613764

Jalilian, H., \& Kirkpatrick, C. (2002). Financial development and poverty reduction in developing countries. International Journal of Finance and Economics, 7(2), 97-108. https://doi.org/10.1002/ijfe.179

Jalilian, H., \& Kirkpatrick, C. (2005). Does financial development contribute to poverty reduction? The Journal of Development Studies, 4l(4), 636-656. https://doi.org/10.1080/00220380500092754

Kakwani, N. (2000). On measuring growth and inequality components of poverty with application to Thailand. Journal of Quantitative Economics, 16, 67-79.

Khan, A. D., Ahmad, I., \& Jan, W. U. (2012). Financial development and poverty alleviation: time series evidence from Pakistan. World Applied Science Journal, 18(11), 1576-1581.

Kraay, A. (2004). When is growth pro-poor? cross-country evidence, IMF Working Paper WP/04/47, Washington D.C.: International Monetary Fund.

Levine, R., Loayza, N., \& Beck, T. (2000). Financial intermediation and growth: causality and causes. Journal of 
Monetary Economics, 46, 31-77. https://doi.org/10.1016/S0304-3932(00)00017-9

McKinnon, R. I. (1973). Money and Capital in Economic Development. Washington: Brooking Institution.

Odhiambo, N. M. (2009). Finance-growth-poverty nexus in South Africa: a dynamic causality linkages. Journal of Socio-Economics, 38, 320-325. https://doi.org/10.1016/j.socec.2008.12.006

Odhiambo, N. M. (2010a). Is financial development a spur to poverty reduction? Kenya's experience. Journal of Economic Studies, 37(3), 343-353. https://doi.org/10.1108/01443581011061311

Odhiambo, N. M. (2010b). Financial deepening and poverty reduction in Zambia: an empirical investigation. International Journal of Social Economics, 37(1), 41-53. https://doi.org/10.1108/03068291011006166

Perez-Moreno, S. (2011). Financial development and poverty in developing countries: a causal analysis. Empirical Economics, 41(1), 57-80. https://doi.org/10.1007/s00181-010-0392-5

Pesaran, H, Shin, Y., \& Smith, R. J. (2001). Bounds testing approaches to the analysis of level relationships. Journal of Applied Econometrics, 16(3), 289-326. https://doi.org/10.1002/jae.616

Phillips, P. C. B., \& Perron, P. (1988). Testing for a unit root in a time series regression, Biometrika, 75(2), 335-346. https://doi.org/10.1093/biomet/75.2.335

Pradhan, R. P. (2010). The Nexus between finance, growth and poverty in India: the cointegration and causality approach. Asian Social Science, 6(9), 114-122. https://doi.org/10.5539/ass.v6n9p114

Rajan, R. G., \& Zingales, L. (2001). The great reversals: the politics of financial development in the 20th century. NBER Working Paper 8178. Cambridge: National Bureau of Economic Research.

Ram, R. (1999). Financial development and economic growth: additional evidence. The Journal of development Studies, 35(4), 164-174. https://doi.org/10.1080/00220389908422585

Schumpeter, J. A. (1912). The Theory of economic development. Harvard University Press, Cambridge, MA.

Shahbaz, M. (2009). Financial performance and earnings of poor people: a case study of Pakistan. Journal of Yasar University, 4, 2557-2572.

Uddin, G. S, Kyophilavong, P., \& Sydee, N. (2012). The causal nexus between financial sector development and poverty reduction in Bangladesh. International Journal of Economics and Financial Issues, 2(3), 304-311.

Uddin, G. S., Shahbaz, M., Arouri, M., \& Teulon, F. (2014). Financial development and poverty reduction nexus: a cointegration and causality analysis in Bangladesh. Economic Modelling, 36, 405-412. https://doi.org/10.1016/j.econmod.2013.09.049

World Bank. (2001). World Development Report 2000/2001: Attacking Poverty. New York: Oxford University Press. 